International Journal of Management (IJM)

Volume 11, Issue 12, December 2020, pp. 288-298. Article ID: IJM_11_12_028

Available online at http://www.iaeme.com/ijm/issues.asp?JType=IJM \&VType=11\&IType=12

Journal Impact Factor (2020): 10.1471 (Calculated by GISI) www.jifactor.com

ISSN Print: 0976-6502 and ISSN Online: 0976-6510

DOI: 10.34218/IJM.11.12.2020.028

\title{
MEDIATIZATION OF POLITICS AND IMPACT ON SOCIETY WITH SPECIAL REFERENCE TO POLITICAL DISCOURSE DURING BIHAR GENERAL ASSEMBLY ELECTION 2020
}

\author{
Ashish Sharma \\ Assistant Professor-II, Amity School of Communication \\ Amity University Madhya Pradesh, Maharajpura Dang, Gwalior, Madhya Pradesh, India \\ Dr Sandeep Kumar \\ Assistant Professor-II, Amity School of Communication \\ Amity University Madhya Pradesh, Maharajpura Dang, Gwalior, Madhya Pradesh, India

\section{Shishir Kr Singh} \\ Research Scholar, Department of Journalism and Mass Communication, \\ MGKVP Varanasi, India

\section{Satnam Singh} \\ Assistant Professor, Amity School of Communication \\ Amity University Madhya Pradesh, Maharajpura Dang, Gwalior, Madhya Pradesh, India
}

\begin{abstract}
Purpose of the study: Elections are symbolic affirmations of a country's functioning democracy. Yet, in a very real sense, they also reflect assertions of asymmetrical power that contribute to legitimising the decision-making authority of those who stand for office and win. The media, which once functioned as merely channels of communication within the election process, have now emerged as independent power centres operating 'autonomously, according to its own economic and symbolic logics'. The capacity of the media to set political agendas, which has been defined as the 'assignment of special relevance to one particular issue or set of information by the source of the message' with the expectation that the audience will respond with heightened attention to the content and format of the message has also been noted.
\end{abstract}

Methodology: The narrative literature review method proposed by Green, Johnson, and Adams (2006) was employed as the method for this article. Relevant peer-reviewed papers published during the period 2011-20 were considered for the narrative review. Appropriate papers were selected by a Google Scholar search using 
Mediatization of Politics and Impact on Society with Special Reference to Political Discourse during Bihar General Assembly Election 2020

the keywords 'Mediatization', 'Political Communication', 'Credibility of Press' and 'India'.

\section{and 'political communication.}

Main Findings: The broad aim of the present paper was to explore the current academic literature in the field of Mediatization of Politics and Crisis of Press credibility in India. The narrative literature review undertaken indicates scant work with limited focus on the broader issues. Traditional media especially electronic media mainly TV has its own influence on voting behaviour and political engagement was the well-explored domain, but the determinants and uniqueness of such communication have not been explored.

Applications of this study: The indications from the review showcase that the magnitude and essence of political communication have changed through the years. The spectrum of political communication through social media has a great role in political and civic engagement. This study will be useful to the researchers in the field of mass communication, journalism, and political science.

Key words: Logistics Metrics, Logistics Performance Measurements, Lean Approach, Warehouse Operations.

Cite this Article: Ashish Sharma, Sandeep Kumar, Shishir Kr Singh and Satnam Singh, Mediatization of Politics and Impact on Society with Special Reference to Political Discourse during Bihar General Assembly Election 2020, International Journal of Management, 11(12), 2020, pp 288-298.

http://www.iaeme.com/IJM/issues.asp?JType=IJM\&VType=11\&IType=12

\section{INTRODUCTION}

\subsection{Mediatization of Politics}

Mediatization is a word that has its origin in German, mediatisierung (Livingstone, 2009). The term "mediatization" firstly emerged among the German-speaking countries. This term was considered to be an awkward term among the native English speaker. Couldry and Hepp (2013) however argue that a term is needed for non-native English speaker to encompass the broad consequences of media in our lives, hence mediatization is coined.

Mediatization comes to theorize broad media-related or mediatic transformations, instead of particular media-caused, that is, transformations in the age where the "media no longer form a distinct sector, but are fully integrated in human life'" (Fornäs, 2014, p. 39), the age of "deeper social penetration of modes of 'media awareness' and 'media relatedness', following recognition that we now 'live in' the media rather than 'live with' them" (Corner, 2018). By this token, the mediatization of politics goes hand in hand with the mediatization of other social domains, from investment banking (Stanley, Mackenzie Davey, \& Symon, 2014) and education (Livingstone, 2014) to romantic love (Storey \& McDonald, 2014) and grieving (Morse, 2018); it is one among our multiple and overlapping "mediatized worlds" (Hepp \& Krotz, 2014). To account, therefore, for the mediatization of politics is also to account for the popularization of the "political" and the politicization of the "popular", that is, the opening of institutional party politics to and merging with various aspects of popular culture, the "personal", the "everyday", and the "spectacular" (Stanyer, 2013; Street, 2016; Williams \& Delli Carpini, 2011), or what I shall refer to as personalization, conversationalization and dramatization of politics.

Mediatization is a theory that contends that media shapes the public opinion and agenda of the political discourse among the general public and society in which it exists. Media has a 
role in setting the dialogue of political communication. Mediatize means how communications transform society, media's impact on political systems, assessing how the processes and systems of communication transform society, media's impact on political communications as the media has emerged as the key institutions. Political communication is a subfield of political science and communication, where factors like- how information spreads and influences the public, polity, and the policymakers, citizens, and the news media; determine the decision making. According to this, the news media has high power over the shaping of the institutions and societies, as they are dependent on the mass media.

In recent times, especially during election campaigns, we have seen the impact of media on politics, that is, how media has influenced the decision making. In present times, the media plays an essential role in politics compared to earlier times. In previous times too, media had a role in political communication in societies. Still, due to societal development in modern times, the present time to be specific, the media has become an indispensable part of politics, that the discourse has been shifted from 'mediated politics' to 'mediatized politics.'

Mediatization of politics, therefore, is a long process in which the media has a significant impact on political communication, policymakers, institutions, and citizens. In India, due to mediatization, politics has lost its autonomy, is increasingly dependent on media coverage to influence the people, and media coverage shapes the political opinion. In the field of journalism, one of its subfield mass media is a communication tool for political institutions as well as society.

\section{POLITICAL DISCOURSE}

The English word 'politics' is derived from three Greek words like 'polis' (city). State), 'polity' (government), and 'politics' (constitution). The original Greek meaning of 'Politics' became old when Hobbes identified it with 'Shakti' and Auguste Comte popularized the trend of 'positivism'.

For Harold Laswell, the study of politics is "The study of influence and influencers" and influencers are those who receive the most what to get "(1951: 295). While, for Robert Dahl, a political system is "a persistent". A pattern of inhuman relations that includes a significant boundary, power, rule or authority "(1965: 6). On similar terms, Michael Curtis stated that," Study of Politics deals with the description and analysis of manners in which power has achieved, exercised and controlled, the purpose for which it is used, the way decisions are made, which factors influence the making of those decisions and the context in which the decision takes place"

In more modern times it was probably George Orwell who first caught our attention toward political Competence of Language. This is seen in his article related to the "Politics and the English language, "where he considers the way in which the language can be used to manipulate thoughts and suggestions, For example he mentioned in his article that " the political speech and writing are largely the defence of indefensible (1969: 225). Examples quoted by George Orwell are based on inverted logic (mentioned in his book 1984) and they can be resonated through the current work on political discourse. Instances like the use of word "pacification" means to the bombing of defenceless villages, or the use of "Rectification of frontier" refers to relocation" or to remove thousands of farmers from their homes. George Orwell was also concerned about the decline of political language and firmly believe that politician is responsible for this decline.

However, it is not just manipulation that is the issue in terms of political language, but It is the goal of such manipulation that is seen as problematic. Orwell also believed that the Politicians want to hide the negative within special formulations, so that the population cannot see the truth or problem / issue in front of them. Later Political Scientist Murray Alleman 
$(1971,1977,1988)$ also stressed upon the symbolic manipulation of reality for the purpose of achieving political goals. Later, Pêcheux $(1982,1978)$ in a more directed political sense, while following Althusser claims that ideology is not merely an abstract system of thought, but becomes actualize in a variety of physical forms, one type of discourse is set about studying material form.

Pecheux strongly argued that the meaning of words will be transformed on the condition of who used them, or in the terms of Foucault (1972) we can defined it as "discourse formations". In discourse formation the words and their interaction may be Interpreted differently within the other. Like conservative or right-wing ideas of "Social benefits" and "defence spending" can differ fundamentally from interpretations of socialist or leftist discourse.

Here, in political discourse the general principle is of transformation. Similar words and phrases can be reinterpreted within various conceptual frameworks. Directly linked to this process is the concept of "representation". Representation here refers to the issue of how language is employed in various ways to represent what we can know, believe, and maybe think.

There are basically two concepts of representation: one is Universalist and other one is Relativist (Montgomery 1992). Universality holds that we understand our world in relation to a set of universal ideological primes. Language, in this view, reflects these universal possibilities. Language is the only medium through which we can express our system of thought, with this system being independent of language itself. While, Relativist position sees language and thought as inseparably related. Our understanding of the world within a relativist perspective is influenced by the available linguistic resources.

Democracy does not mean contesting and winning elections. The quality of a country's democracy is gauged from the fact that leaders and managers of democratic institutions follow democratic norms and values in principle and practice. The language used by political leaders in a fragmented democratic country needs to reflect decency and respect for difference of views and opinions; And the inevitability, importance of other political groups. When a nation's public discourse becomes vicious and biased, fully democratic politics begins to diverge. In recent years, with the rise of ultra-right ideology in various parts of the world, the language publicly used by leaders has become vicious and personal. A loud rhetoric based on half-hearted truth rather than bringing together the anger, hatred and division of people in society.

The language of public discourse matters a lot in any democracy. As psychologists have found, many political leaders are regularly using offensive languages in public as if they are "expressing their true feelings" to project themselves differently than their peers Those who are afraid to tell the truth. However, the 'unscrupulous truth' made by the loud politicians is not a truth, but a populist statement to further their and their parties' narrow interest in electoral politics.

Mark Twain once said, "The difference between a near-perfect word and a right word is a really big case - it's the difference between a lightning bug and a lightning." Forget almost the right words, political leaders in India have become masters of using all the wrong words, and this trend has greatly eroded the level of public discourse in the country. On the eve of elections in Himachal Pradesh and Gujarat, political rhetoric has again reached a new level.

\section{CASE STUDY: GENERAL ELECTION BIHAR 2020}

Famous American Film Director, Woody Allen, once said, "In Beverly Hills, they don't throw their trash away. They include it in television shows." While this quote applies specifically to 
$24 \times 7$ news channels in India, claiming that the political discourse in the country is difficult to catch up even outside the television studio.

The election in Bihar were very interested this time as this was the first general election held during COVID-19 pandemic. The voting has been divided into three phases which concludes on $7^{\text {th }}$ November 2020. These polls would also test the ability of Election Commissioner of India (ECI) to conduct safe voting especially in Bihar which is famous for its poor health infrastructure.

There are three factor which are very crucial in these elections. Firstly, Nitish Kumar looking for a fourth consecutive term in the Chief Minister office and there is a possibility if anti-incumbency against him. Secondly, the mishandling of migrants during the pandemic times along with the floods in north Bihar. Lastly, the situation of deteriorating law and order situation under his leadership.

Along with this, Nitish Kumar party Janta Dal United (JDU) is going to contest election with Bhartiya Janta Party(BJP), Hindustani Awam Morcha(HAM) and Vikassheel Insaan Party (VIP) under the banner of National Democratic Alliance (NDA). However NDA's ally Lok Janta Party(LJP) at center has also decided to contest election independently and has focused its fire on Nitish Kumar, with considerable impact.His main opponent Tejaswi Yadav's party (Rashtriya Janta Dal (RJD) have done alliance with Indian national Congress (INC), left wing parties which includes Communist Party of India (CPI), Communist Party of India -Marxist (CPI-M) and Communist party of India-ML (CPI-ML) under the banner of Mahagathbandhan. Even this become interested after the alliance of AIMIM

In between this another former ally and trustable leader of Nitish Kumar Upendra Kushwaha pulled the party from the Rashtriya Janata Dal-led grand alliance (Grand Alliance). The party aligned with Uttar Pradesh-based Bahujan Samaj Party and minority. Janwadi Party (Socialist). The UDSA consisted of veteran socialist Devendra Prasad Yadav and All India Majlis-e-Ittehadul Muslimeen under the leadership of Samajwadi Janata Dal Democratic. Lastly, On $8^{\text {th }}$ October 2020, UDSA and Bahujan Samaj Party were merged into an alliance called Grand Democratic Secular Front (GDSF), which also included Suheldev Bharatiya Samaj Party.

Here we will discuss some slogans used by political prties to set up political discourse in the General Assembly election of Bihar.

\subsection{Return of Jungle-Raj}

At a rally in Muzaffarpur, the Prime Minister mentioned the 15-year rule of Tejashwi Yadav's parents Lalu Yadav and Rabri Devi as Modi warned people against returning to "darkness". "PM Modi said," The people of Bihar have no expectation from the "Crown Prince of Jungle Raj"

\subsection{Nine children Remark}

Addressing an election rally Chief Minister Nitish Kumar took a sarcasm to Yadav's father, RJD supremo and former CM Lalu Prasad Yadav, for having nine children, including Tejashwi and Tej Pratap, and seven daughters. Without naming the RJD supremo, Kumar accused him of not believing his daughters and promoting both his sons. "He (Lalu Yadav) has given birth to eight-nine children. She has no faith in her daughters. Their sons were born after many years. What kind of Bihar do you want? He has no faith in her daughters. Their sons were born after many years. What kind of Bihar do you want? You can wonder to what extent Bihar will be ruined. Everything will be destroyed," Kumar said. 


\section{3. "If you don't want to vote for us, don't but don't create nuisance. You will do harm to the person for whom you're here"}

Chief Minister Nitish Kumar said this during his one of election rally in Chapra Bihar, when some people in crowd raised slogan in support of Rashtriya Janta Dal leader Lalu Prasad Yadav. Nitish Kumar also accused that these people might be paid off by RJD leaders to raise anti Nitish slogan in his public rally.

\section{4. "Terrorists whom we are eliminating from Kashmir will escape and take shelter in Bihar if RJD is elected to power in the state. We will not let this happen,"}

Mr. Nityanand Rai, Minister of State (MoS) while addressing public rally in Bihar, gave this controversial remark and somewhere through this tried to give message to the people of bihar that if RJD comes to power in state then terrorists will escape Kashmir and may take shelter in Bihar. Later Bhartiya Janta Party leader Bhupendra Yadav supported his remark and clarify that MoE Mr Nityanand Rai wants to state that BJP is fighting against terrorism and his remark was twisted.

\subsection{To choose "hope over fear, unity over division... and truth over lies".}

$\mathrm{P}$ Chidambaram senior leader of Indian National Congress in a series of tweet urged the voters of Bihar - "to choose hope over fear, unity over division... and truth over lies". He also referred the remarks on US Presidential Joe Biden's remark, where he quoted" We choose hope over fear, unity over division, science over fiction and yes, truth over lies".

\section{6. "Free coronavirus vaccination for all"}

While releasing BJP's manifesto Union finance minister Nirmala Sitharaman announced that 'As soon as a COVID-19 Vaccine available for promotion at mass scale, every person in Bihar will get free vaccination". She also proclaims it as the first promise that BJP had mentioned in their manifesto. This was highly criticized by the political leaders across the country and they questioned the intention and alleged it as an attempt ion of "appalling" attempt to use vaccine for BJP's political agenda.

\section{7. 'Tejashwi a 9th fail'}

Previous chief minister of Maharashtra and Election -in-Charge of Bihar Mr Devendra Fadnavis commented upon the educational qualification of RJD Leader and Mahagathbandhan Chief Ministerial candidate Mr Tejaswi Yadav. While taking upon a dig on Tejasvi's qualification he said" A person who is himself uneducated can't think about better education". Through this statement he also challenged the vision of Tejasvi Yadav for Bihar. This is what Devendra Fadnavis said

"On one side is our NDA CM Nitish Kumar who is an engineer, and on the other side is RJD's CM candidate - a ninth (std) fail. If CM himself is ninth fail, will he think of good education? Will he think about the future of your children? RJD is concerned about their family and not the people," said Fadnavis. He said that under the NDA government medical colleges, ITI, Engineering and polytechnical colleges were established"

\subsection{For how long will PM Modi keep Bihar from "special status", asks Tejashwi During one of the rallies}

Rashtriya Janata Dal (RJD) leader and Mahagathbandhan's chief ministerial candidate Tejashwi Yadav attacked prime minster Narendra Modi and reminded people of Bihar for not 
giving "special state" status category to Bihar. He also criticized Narendra Modi for remaining silent on the Nitish Kumar when it comes to scams, worst law situation, corruption in Bihar during his government.

\section{9. "19 Lakh Jobs Promise Like That Of ₹ 15 Lakh"}

Senior Leader and former president of Indian National Congress Mr Rahul Gandhi take jibe on prime minister Mr Narendra Modi by hitting at their manifesto which claims to give 19lakh jobs to the youth of Bihar. He also compared this with the same kind of promise Modi did during the 2014 Lok sabha elections where he assured everyone to bring back black money and deposit 15 Lakh INR in the accounts of people. He also alleged Modi and Nitish kumar for 'breaking the backbone' of farmer and small \& medium business within state with their policies.

\subsection{0. "Those who have tied up with the Jungle Raj people, you know what they want...They do not want you to chant 'Bharat Maata ki jai'.}

Prime Minister Narendra Modi during his rally in Sasaram put his remark on opposition and try to convey that people in opposition are against Lord Ram. He said "Those who have tied up with the Jungle Raj people, you know what they want...They do not want you to chant 'Bharat Maata ki jai'. He also takes jibe on Tejasvi and Rahul Gandhi by calling them 'double Yuvraj'. He also describes the opposition leaders as "obstructionist".

\section{RESEARCH QUESTIONS}

Q1. Do you think media especially election-based programme's influence the voting behaviours of individuals during the elections?

Q2. Do you think media helps to enhance your political awareness through various shows on politics?

Q3. Do you think that media have a significant influence on the perceptions of voters?

Q4. Do you think that media helped you to modified your view or opinion about any political candidate or political issue?

Q5. Do you think opinion polls or election surveys shown on media influence the viewer during elections?

\section{RESEARCH METHODOLOGY}

The time frame which we have covered for our research is till second phase of general election i.e. till $3^{\text {rd }}$ November 2020 which includes voting in almost 165 seats out of 243 seats in Bihar. Here we have framed a questionnaire based on literature review and previous studies. We have distributed the questionnaire among the young voter's in the respective state by using Google form as a medium. Mostly respondents were first time voters.

\section{RESULTS \& ANALYSIS}

Q1. Do you think media especially election-based programme's influence the voting behaviours of individuals during the elections? 


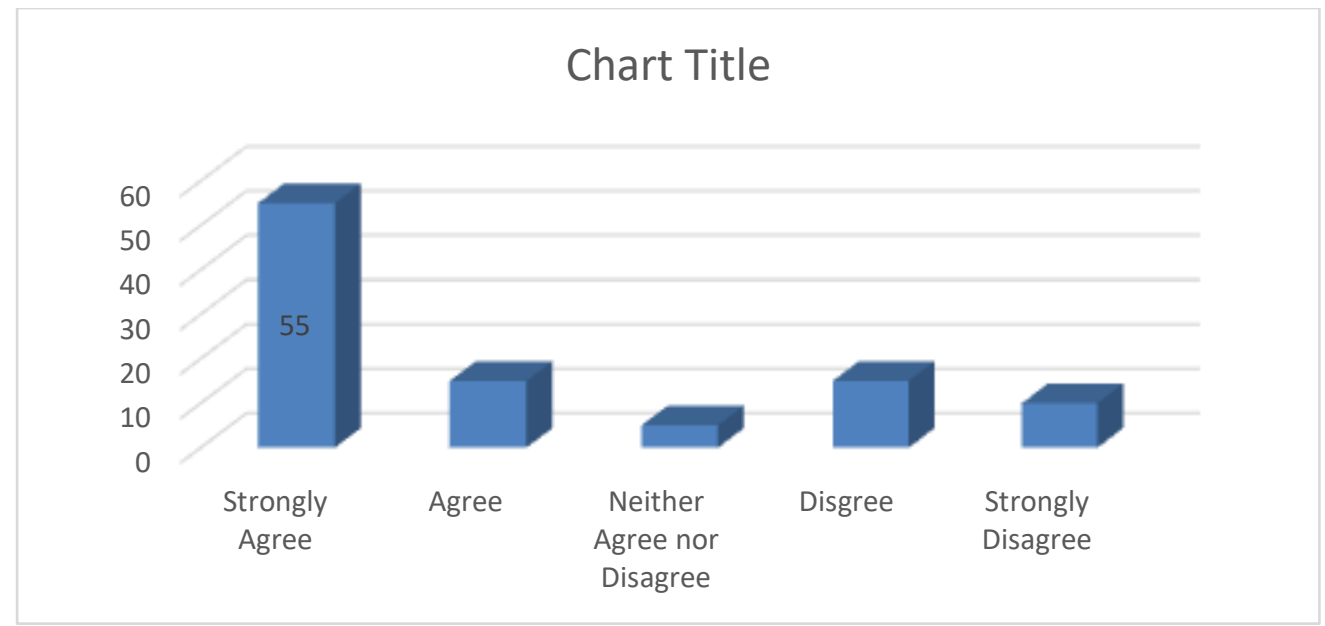

Figure 1

Mostly respondents are strongly agreed to the statement and they believe debate shows like Kaun banega Mukhyamantri or Dangal / Desh ki Baat may influence the voting behaviour of people. As we can see, in fig (1) $55 \%$ respondents firmly believe while rest are $15 \%$ who agreed, $5 \%$ are who aren't sure and $15 \%$ are those who disagreed with the statement and $10 \%$ are those who totally disagreed with the statement. However, according to the responses, it clearly shows that shows like Kaun Banega Mukhyamantri or election yatra influenced the voting behaviour of individuals during the elections.

Q2. Do you think media helps to enhance your political awareness through various shows on politics?

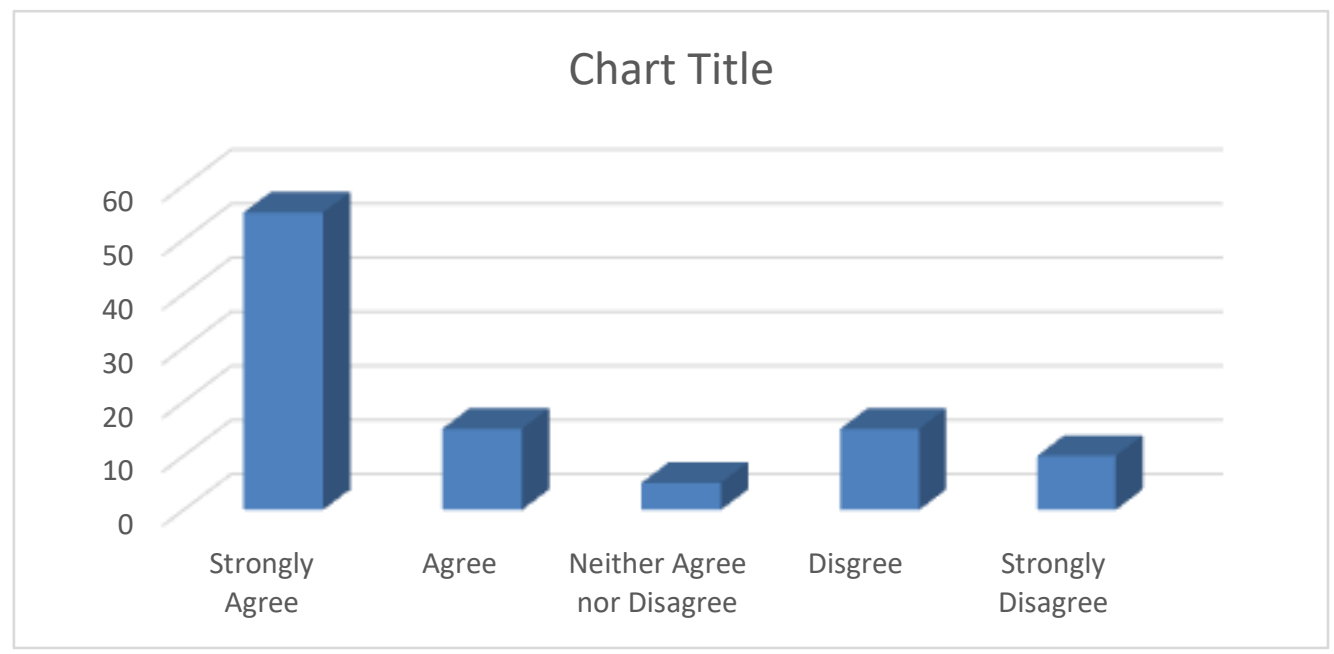

Figure 2

Through this statement, it's clear that $55 \%$ of respondent believe that prime time shows or debates enhance their knowledge or their political awareness about the issues. While $15 \%$ are agreed with the statement and 5\% are not sure about this phenomenon and rest $15 \%$ totally neglect this possibility and rest $10 \%$ strongly reject this idea of getting political awareness through these shows. Somewhere it shows majority of people believe that prime time shows or debates enhance their knowledge or helps to increase their political awareness while other remain rigid toward their political ideology and may be not have the same views on the statement. 
Q3. Do you think that media have a significant influence on the perceptions of voters?

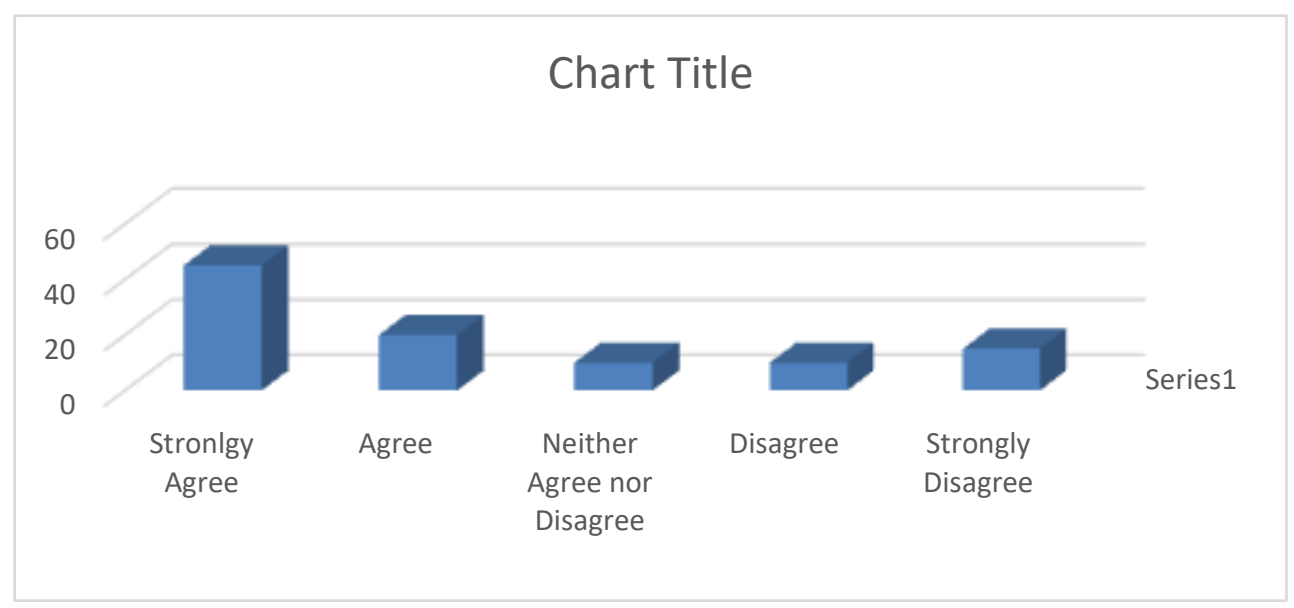

Figure 3

Yes, we are much sure that media is having a strong influence on the perception and we can see that in the way media play its role as a gatekeeper. Media selectively broadcast or publish content, which influence the voters. We can also see, here in figure (3) that almost $65 \%$ people are agreed with the statement and $25 \%$ believed that it doesn't influence the voters. By showing program, policies or news in media channels have their way of influencing voters regarding election. Political unawareness is also a big reason voter's get influenced by media channels especially first-time voters.

Q4. Do you think that media helped you to modified your view or opinion about any political candidate or political issue?

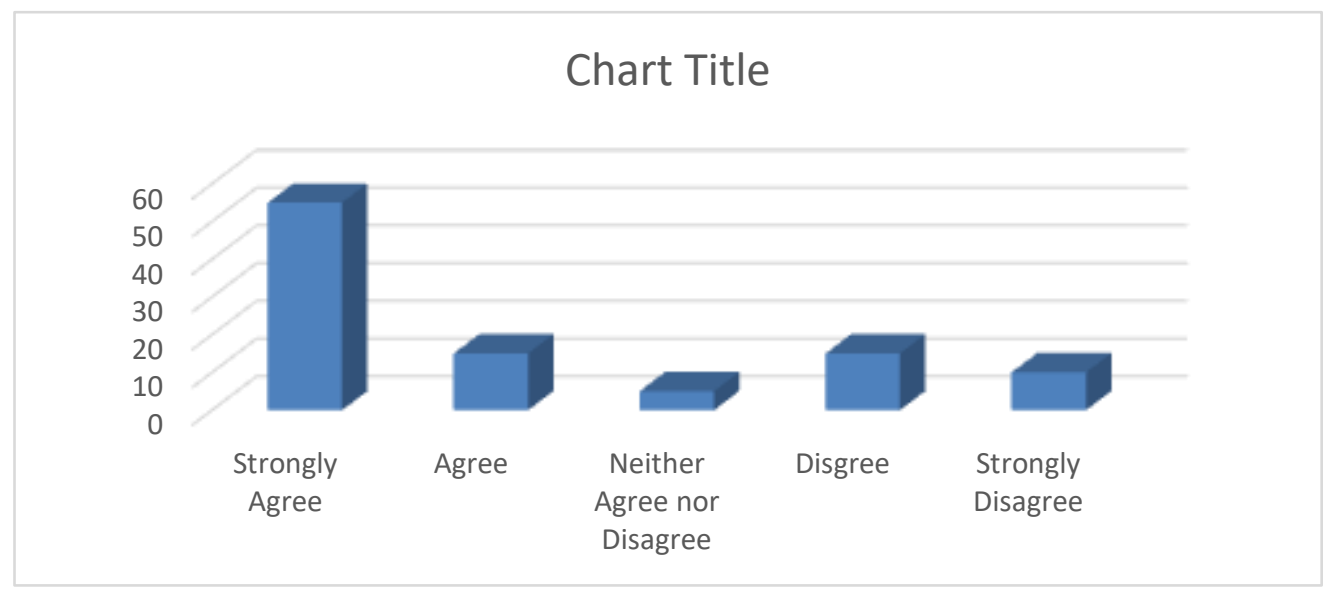

Figure 4

As per statement it clearly shows that $55 \%$ of respondent are clearly agreed with the statement that media channel helped them to make their own opinion or perception about the issues while $15 \%$ are agreed with the statement, $5 \%$ are neither agree or disagree and $15 \%$ disagree to the statement and $10 \%$ strongly disagree with the statement. Somewhere it shows that the individual is rigid and to some extent they stick to their own political ideology and act according to that. 
Q5. Do you think opinion polls or election surveys shown on media influence the viewer during elections?

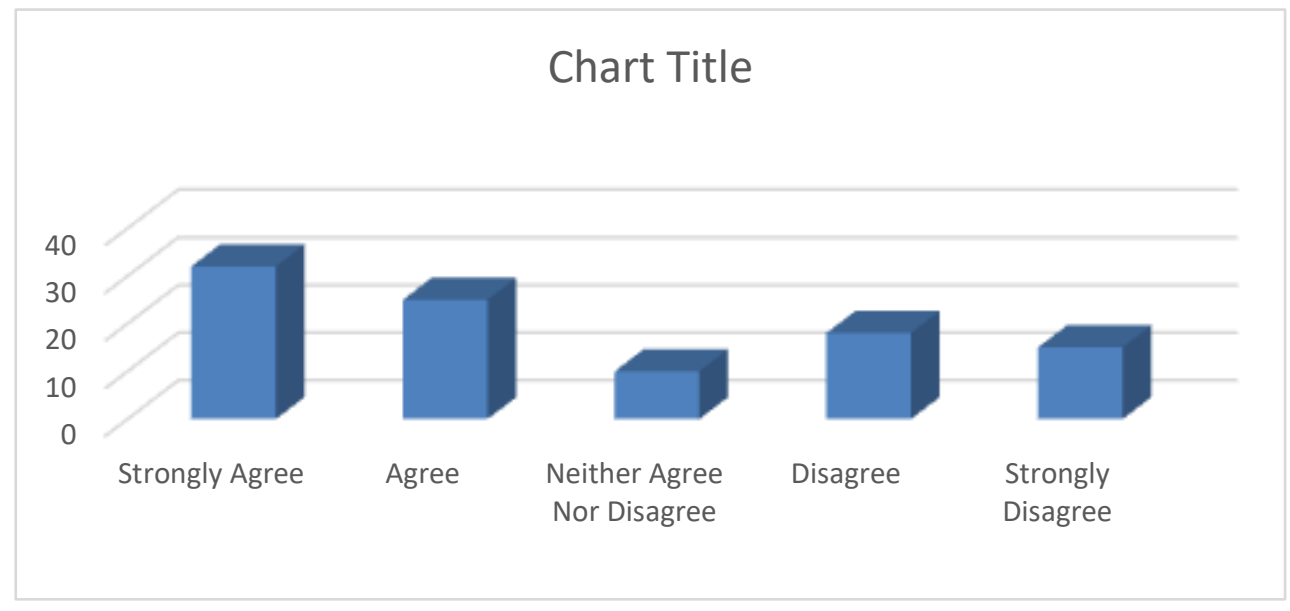

\section{Figure 5}

As per statement $32 \%$ respondent are strongly admitting that opinion poll and election survey done by media channels during elections strongly influence their opinion. While $25 \%$ are agreed to this statement, but overall if we see $57 \%$ respondents shows strong belief about the concept and agreed to the statement. One thing which we also find out during our research, voters especially first-time voters get more influence in this way of media coverage as they aren't political aware, so they stick to the media coverage on various issues and act according to it.

\section{CONCLUSION}

Mediatization of politics has given media tremendous power over shaping public opinion and media has a massive role in shaping the political agenda, especially during the elections. The political institutions, politician, authorities; everyone is dependent on the media. It has been on the rise since the 2014 General Elections, where the press played an essential role in shaping the image of Narendra Modi. After 2014, we have seen the same trend in almost every election. We have seen that earlier it was traditional media which influenced people but now adays new media is also plays its significant role. In term of political discourse, language is a crucial determinant which helps to set an agenda. So we can say, that discourse always played an vital role when it comes to election.

\section{REFERENCES}

[1] Foucault, M. (1972) The Archaeology of Knowledge. London: Tavistock Publications.

[2] Montgomery, M. (1992) An Introduction to Language and Society. London: Routledge.

[3] Orwell, G. (1969) Politics and the English language. In W. F. Bolton and D. Crystal (eds), The English Language 414 John Wilson Vol. 2: Essays by Linguists and Men of Letters, 18581964. Cambridge:

[4] Pêcheux, M. (1982) Language Semantics and Ideology. London: Macmillan.

[5] Pêcheux, M. (1978) Discourse-structure or event. In C. Nelson and L. Grossberg (eds), Marxism and the Interpretation of Culture. London: Macmillan, 251-66. 
[6] https://www.hindustantimes.com/bihar-election/pm-modi-also-has-six-siblings-tejashwiyadav-responds-to-nitish-kumar-s-comment-on-his-family/storyaMCeBtXnivIK9Dj8ZKAjAJ.html

[7] https://www.republicworld.com/india-news/elections/fadnavis-compares-engineer-cm-nitishto-rjds-9th-fail-tejashwi.html

[8] https://www.deccanherald.com/video/news/bihar-election-pro-lalu-slogans-raised-at-nitishrally-905395.html 